\title{
APLIKASI MODEL PELLA-TOMLINSON PADA PENGELOLAAN SUMBER DAYA PERIKANAN KAKAP MERAH DI INDONESIA Pella-Tomlinson Model for Red Snapper Management in Indonesia
}

\author{
*Sonny Koeshendrajana', Mira', Zuzy Anna', Duto Nugroho³, \\ Umi Muwamanah ${ }^{1}$ dan Yesi Dewita Sari ${ }^{1}$ \\ ${ }^{1}$ Balai Besar Riset Sosial Ekonomi Kelautan dan Perikanan \\ Gedung BRSDM KP I Lt. 4 \\ Jalan Pasir Putih Nomor 1 Ancol Timur, Jakarta Utara, Indonesia \\ Telp: (021) 64711583 Fax: 64700924 \\ ${ }^{2}$ Fakultas Perikanan dan IImu Kelautan, Universitas Padjajaran, Indonesia \\ ${ }^{3}$ Pusat Riset Perikanan, Badan Riset dan Sumber Daya Manusia Kelautan dan Perikanan, \\ Kementerian Kelautan dan Perikanan, Indonesia \\ Diterima tanggal: 25 April 2018 Diterima setelah perbaikan: 29 Oktober 2018 \\ Disetujui terbit: 17 Desember 2018 \\ "email: skoeshen@gmail.com
}

\begin{abstract}
ABSTRAK
Tujuan dari penelitian ini adalah memodelkan pengelolaan sumber daya perikanan kakap merah di Indonesiadengan menggunakan model Pella-Tomlinson. Penelitian ini dilakukan pada tahun 2016, dengan data perikanan kakap merah Indonesia. Model surplus produksi bio-ekonomi yang digunakan dalam penelitian ini adalah model Pella-Tomlinson. Hasil analisis mengindikasikan, pertama jumlah upaya tangkap aktual berada diatas jumlah jumlah upaya lestari (MSY). Jika pengelolaan perikanan dilakukan berdasarkan prinsip perikanan lestari, maka mulai tahun 2020 upaya tangkap di bawah jumlah upaya lestari (MSY). Kedua, dalam kondisi bussiness as ussual, terjadi kenaikan bio-massa ikan semenjak tahun 1980 sampai pada tahun 2000, akan tetapi dari tahun dari tahun 2000 sampai tahun 2014 terjadi penurunan bio-massa ikan. Jika tidak ada intervensi kebijakan untuk mengurangi laju degradasi sumber daya maka penurunan biomassa akan terus terjadi hingga tahun 2050. Jika pemerintah melakukan intervensi kebijakan pengelolaan perikanan secara berkelanjutan, akan terrjadi kenaikan biomassa dari tahun 2020 sampai dengan tahun 2050. Ketiga, sejalan dengan penurunan bio-massa karena tidak adanya intervensi kebijakan pengelolaan perikanan kakap merah secara berkelanjutan, maka keuntungan yang diterima nelayan akan menurun, karena terjadi penurunan hasil tangkapan. Tapi jika pemerintah mengeluarkan kebijakan pengelolaan perikanan kakap merah secara berkelanjutan seperti pembatasan upaya penangkapan, maka keuntungan yang diterima nelayan akan meningkat lagi dari tahun 2020 sampai dengan tahun 2050.
\end{abstract}

Kata Kunci: pella-tomlinson; pengelolaan; sumber daya; kakap merah

\section{ABSTRACT}

The purpose of this study to develop a management model for red snapper fishery using a Pella Tomlinson Model. The research was conducted in 2016, for the national snapper fisheries obtained from official yearly landing statisctic data to get the time series catches and efforts. Surplus production bioeconomic was utilized with modified Pella and Tomlinson model for the growth model. The analysis shows that first, total efforts deployed without any kind of management (e.g. stay as an open access) will yield higher effort than maximum efforts at maximum sustainable level yield (MSY). This is a consequence of the increasing rate of red snapper efforts between 1980-2014. If fishery management is kept at the sustainable level of total efforts, then in 2020, total efforts will be less than the MSY level. Second, biomass increased between 1980-2000 and then decreased after 2000 until 2014. If there will be no intervention to the depletion of fishery resources, the fishery will be completely depleted in 2050. Third, when the snapper biomass decreases, the cathes will decrease as well. Hence, that total profits from the fishery will decrease. However, some intervention and magement measures will be put in place, such as limiting the total efforts, the cathes and profits will bounce back and increase after 2020 and the years after.

Keywords: pella-tomlinson; management; resources; red snapper 


\section{PENDAHULUAN}

Pentingnya riset model bio-ekonomi pengelolaan sumber daya perikanan kakap merah di Indonesia karena kakap merah merupakan ikan demersal yang rawan terhadap eksploitasi. Sumber daya perikanan kakap merah dalam kondisi kritis itulah yang menjadi latar belakang dari penelitian ini. Ikan demersal memiliki karakteristik yang berbeda dengan ikan pelagis. Adapun karakteristik dari perikanan demersal adalah memiliki aktivitas gerak yang rendah, membentuk gerombol yang tidak terlalu besar, dan bermigrasi tidak terlalu jauh ( Sriati, 2011),. Sifat-sifat tersebut sangat berbeda dengan perikanan pelagis dimana bermigrasi dalam jarak yang jauh dalam bentuk gerombolan besar.

Ikan kakap merah yang memiliki karakteristik demersal seperti memiliki aktivitas gerak yang rendah menyebabkan ikan jenis ini rawan terhadap pengaruh lingkungan dan eksploitasi. Kerusakan lingkungan sangat mempengaruhi sumber daya ikan ini, karena ikan kakap merah tidak bisa bermigrasi jauh untuk mencari habitat yang baru seperti Ikan Tuna bila terjadi kerusakan lingkungan pada habitat lamanya. Pengaruh ekploitasi sangat rawan terhadap kelangsungan sumber daya ikan kakap merah karena daerah distribusi yang sempit dan dekat dengan dasar perairan, ikan jenis ini kurang tahan terhadap pengaruh eksploitasi. Artinya bila terjadi peningkatan intensitas penangkapan terhadap jenis ikan ini maka pengaruh tekanan cenderung meningkat pula (Sriati, 2011).

Menurut Usmanm et al., 2014, kegiatan penangkapan ikan di wilayah perairan Indonesia sudah mendekati kondisi yang kritis, khususnya sumber daya ikan demersal contohnya Kakap Merah di WPP Laut Jawa atau WPP 712 (Kepmen
KP nomor: KEP.45/MEN/2011). Kondisi kritis tersebut dipicu oleh tingginya tekanan penangkapan diwilayah pesisir pantai. Padahal ikan kakap merah termasuk ikan demersal kategori ekonomis tinggi karena harga nya yang relatif tinggi.

Penangkapan kakap merah di WPP Laut Jawa yang mendekati kondisi kritis ini perlu diwaspadai, meskipun sifat sumber daya ikan dapat diperbaharui (renewable) namun perlu kehatihatian dalam pemanfaatannya untuk menjamin keberlanjutan, baik dalam jumlah maupun kemampuannya untuk regenerasi (Santoso, 2016). Pauly et al. (2002) mengungkapkan bahwa kegiatan usaha perikanan merupakan suatu usaha ekstrasi yang sudah menjadi industri. Usaha perikanan pada kondisi kritis terjadi karena usaha perikanan tersebut lebih melihat aspek ekonomi ketimbang melihat aspek lainnya seperti aspek lingkungan dan aspek ekologis. Hal ini mengakibatkan usaha ekstrasi pada sumber daya perikanan melebihi kapasitas maksimum daya dukung sumber daya dan daya dukung lingkungan. Akibat selanjutnya adalah usaha perikanan pada kondisi kritis mengakibatkan kerusakan dan kepunahan pada sumber daya. Penelitian ini ditujukan untuk mengetahui kondisi sumberdaya dengan menerapkan model Pella Tomlison.

\section{METODELOGI}

\section{Waktu dan Lokasi Penelitian}

Penelitian dilakukan pada bulan Januari - Desember 2016. Ada pun data diambil secara nasional, dimana lokasi penelitian berada di lokasi utama wilayah penangkapan perikanan Kakap Merah, seperti yang terlihat pada Gambar 1.

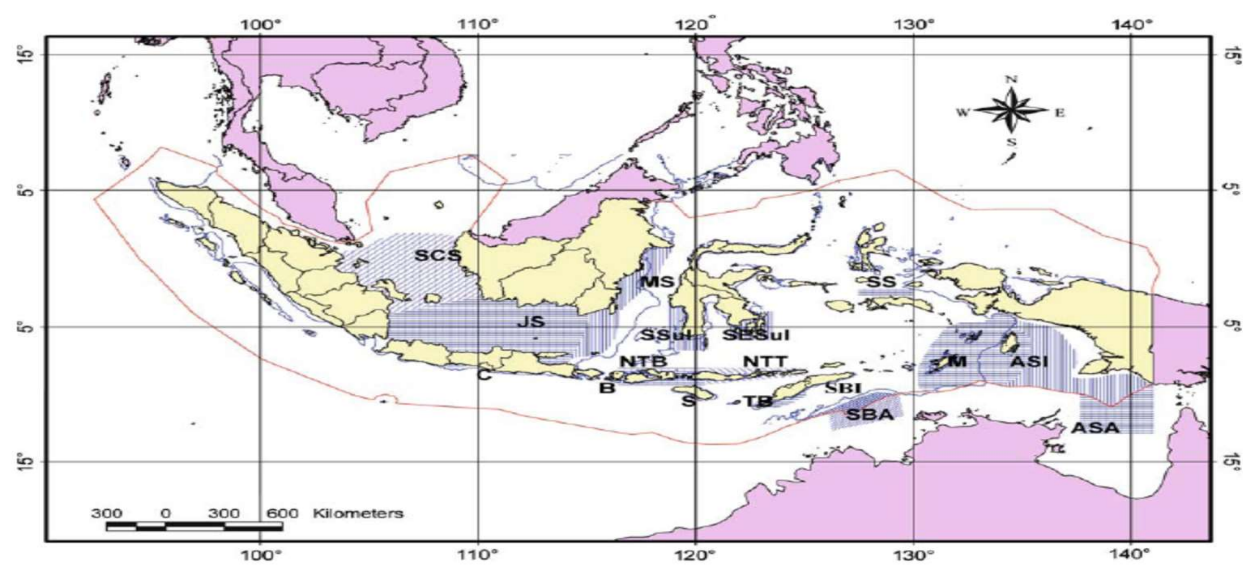

Gambar 1. Peta Lokasi Utama Wilayah Penangkapan Kakap Merah Antara Perairan Indonesia dan Australia (Diadopsi dari Blaber et al. (2005).

Figure 1. Location of The Major Area Sectors of The Australian and Indonesian Waters Fisheries for Snapper (Adopted from Blaber et al. (2005). 


\section{Jenis, Sumber dan Cara Pengumpulan Data}

Studi ini menggunakan data hasil tangkapan (catch) dan upaya penangkapan (effort) menurut jenis alat penangkapan standar yang digunakan pada suatu daerah tangkapan tertentu serta data sosial ekonomi berupa biaya usaha penangkapan dan harga ikan kakap merah. Adapun jenis data dan sumber data dapat dilihat pada Tabel 1.

Data utama yang digunakan dalam penelitian ini adalah data sekunder. Data sekunder diperoleh dari Direktorat Jenderal Perikan Tangkap, Badan Pusat Statistik, Statistik Perikanan Tangkap yang dikeluarkan oleh Ditjen Perikanan Tangkap, data yang dihimpun oleh asosiasi perikanan, dan data I-Fish.

\section{Metode Analisis Data}

Pada penelitian ada 2 aspek yang dipertimbangkan yaitu yaitu aspek sosial ekonomi dan aspek sumber daya. Aspek sumber daya meliputi aspek biologi perikanan dan aspek sumber daya. Pada aspek biologi, faktor yang harus dipertimbangkan adalah adalah pertumbuhan intrinsic ikan. Pada penelitian ini hal yang pertama diidentifikasi adalah menentukan upaya tangkap dan kemudian membuat model perikanan. Upaya penangkapan yang dikenal dengan fishing effort. Menurut Sahri (2004), pengertian fishing effort secara sederhana mewakili berbagai peubah biologis, yaitu pertumbuhan, mortalitas dan tambahan individu ikan baru ke dalam satu istilah, yaitu : "hasil tangkap". Dengan demikian fishing effort merupakan gambaran tentang jumlah armada penangkapan ikan mencakup daya tangkap alat, lama operasi melaut, dan keterampilan Anak Buah Kapal (ABK). Secara ekonomi, fishing effort mewakili keterampilan ABK dan modal (kapal dan alat tangkap) yang digunakan. Sehingga, tambah Sahri (2004) fishing effort merupakan konsep yang kompleks tergantung pada karakteristik biologi ikan dan cakupan ekonominya.

Analisis data dilakukan secara kuantitatif dan kualitatif. Aspek yang dilihat yaitu aspek biologi dan aspek ekonomi. Aspek biologi yaitu menghitung fungsi intrinsik pertumbuhan ikan yang meliputi tingkat pemtumbuhan intrinsik ikan (r), koefisien kemampuan alat tangkap (q) dan carrying capacity (K). Aspek ekonomi melihat parameter ekonomi meliputi harga dan biaya. Zulbarnaini (2015), dalam penelitiannya melihat pengelolaan perikanan lemuru dimana tidak hanya aspek biologinya yang dilihat,akan tetapi ijuga aspek ekonomi. Kurva penawaran ikan tersebut bersifat akan meningkat dengan meningkatnya harga sampai batas ketersedian stok, dan kemudian menurun kembali dengan meningkatnya harga. Analis data tersebut di atas dilakukan melalui

Tabel 1. Jenis Data dan Sumber Data.

Table 1. Type of Data and Source of Data.

\begin{tabular}{|c|c|}
\hline Jenis Data/Type of Data & Sumber Data/Source of Data \\
\hline $\begin{array}{l}\text { Hasil tangkapan kakap merah/ Catch } \\
\text { of red snapper }\end{array}$ & $\begin{array}{l}\text { Pusat Penelitian dan Pengembangan Perikanan, Direktorat Jenderal } \\
\text { Perikanan Tangkap / Directorate For Fish Resource and Management } \\
\text { (PSDI), Centre for Fisheries Research and Development }\end{array}$ \\
\hline $\begin{array}{l}\text { Upaya tangkap per alat tangkap/ } \\
\text { Effort by type of fishing gear }\end{array}$ & $\begin{array}{l}\text { Pusat Penelitian dan Pengembangan Perikanan, Direktorat Jenderal } \\
\text { Perikanan Tangkap/ Directorate For Fish Resource and Management } \\
\text { (PSDI), Centre for Fisheries Research and Development }\end{array}$ \\
\hline $\begin{array}{l}\text { Penerimaan dan struktur ongkos } \\
\text { usaha per jenis ikan dan per alat } \\
\text { tangkap/ Revenue and cost structure } \\
\text { by fishing gear and target species }\end{array}$ & $\begin{array}{l}\text { Data wawancara dengan nelayan, Pusat Penelitian Sosial Ekonomi } \\
\text { Kelautan dan Perikanan, Pusat Penelitian dan Pengembangan Perikanan, } \\
\text { Direktorat Jenderal Perikanan Tangkap dan Biro Pusat Statistik/ Centre } \\
\text { for Marine and Fisheries Socio Economic Research, Central Bereau of } \\
\text { Statistics, Centre for Fisheries Research and Development }\end{array}$ \\
\hline $\begin{array}{l}\text { Log book perikan per alat tangkap/ } \\
\text { Log book by type of fishing gear }\end{array}$ & $\begin{array}{l}\text { Pusat Penelitian dan Pengembangan Perikanan, Direktorat Jenderal } \\
\text { Perikanan Tangkap/ Directorate For Fish Resource and Management } \\
\text { (PSDI), Centre for Fisheries Research and Development }\end{array}$ \\
\hline Harvest control rule & $\begin{array}{l}\text { Pusat Penelitian dan Pengembangan Perikanan, Direktorat Jenderal } \\
\text { Perikanan Tangkap Directorate For Fish Resource and Management (PSDI), } \\
\text { Centre for Fisheries Research and Development }\end{array}$ \\
\hline Export and import & $\begin{array}{l}\text { Direktorat Jenderal Daya Saing Perikanan/ DG of Fish \& Fisheries Product } \\
\text { Competitiveness Improvement }\end{array}$ \\
\hline Coral reef fish & $\begin{array}{l}\text { World Wild Fund(WWF), RARE, The Nature Conservancy (TNC), The } \\
\text { Wildlife Conservation Society (WCS), Conservation of Indonesia (CI) }\end{array}$ \\
\hline
\end{tabular}

Sumber: Diskusi Tim Teknis KKP-UCSB, 14 November 2015./

Source: Discussed of MMAF-UCSB Technical Team, 14 November 2015. 
pendekatan bioekonomi dengan memanfaatkan model biologi surplus produksi (surplus production model).

Pada penelitian ini model yang digunakan non equilibrium state model untuk memperoleh Surplus Production Model. Non equilibrium state modeldikembangkan oleh Walter-Hilborn (1976), dimana model ini bisa digunakan untuk menduga nilai MSY sumber daya perikanan juga dapat menduga nilai parameter populasi (Hilborn, 1976). Surplus Production Model/SPM sudah lama dipratikan baik bersifat statis maupun dinamis, dimana model yang dikembangkan menggunakan basis model dasar biologi. Karya tulis ilmiah yang diterbitkan secara internasional masih sangat terbatas.

Menurut Nabunome (2007), secara biologi ikan mempunyai siklus untuk memijah, bertelur, telur menjadi larva, ikan muda dan baru kemudian menjadi ikan dewasa. Bila salah satu siklus tersebut terpotong, misalnya karena penangkapan, maka sumber daya ikan tidak dapat melangsungkan daur hidupnya. Hal ini dapat menyebabkan ancaman kepunahan sumber daya ikan. Oleh karena itu diperlukan suatu pengaturan musim penangkapan. Fauzi (2003) mengungkapkan sumber daya perikanan memiliki cadangan yang terbatas sehingga ekploitasi terhadap sumber daya perikanan akan menghabiskan sumber daya tersebut.

Permasalahan perikanan lebih fokus pada maksimalisasi penangkapan pada satu sisi, tapi disisi lain mengabaikan faktor produksi dan biaya yang dipergunakan dalam usaha perikanan, karena itu pendekatan bioekonomi dibutuhkan dalam optimalisasi sumber daya perikanan. Gordon (1954) melakukan pemodelan terfokus pada konsep faktor produksi biologi, kemudian dikembangkan oleh Schaefer (1957ª $1957^{\text {b}}$ ) berdasarkan konsep dasar bioekonomi yang disebut dengan teori GordonSchaefer.

Menurut Koeshendrajana et al. (2008), lingkungan alam sangat berpengaruh besar terhadap kondisi stok sumber daya ikan. Perubahan kondisi lingkungan akan berpengaruh terhadap daya dukung (carrying capacity) sumber daya dan stok ikan. Koeshendrajana et al. (2008) menambahkan bahwa untuk memelihara sumber daya perikanan yang dapat pulih, pertanyaan yang sering muncul adalah seberapa besar ikan dipanen atau diproduksi sehingga sumber daya dapat dimanfaatkan secara maksimum dan berkelanjutan yang diharapkan dapat memperbaiki kondisi sumber daya dan masyarakat perikanan.

Pemanfaatan perikanan secara berkelanjutan pada penelitian ini berkaitan pengaturan jumlah effort yang diperbolehkan. Pada kebijakan ini, pemerintah melakukan kebijakan pengontrolan CPUE dan fishing effort dengan mengawasi kekuatan mesin kapan, tipe dan ukuran jaring (Mira\& Sari, 2012). Berarti secara teoritis, melakukan kebijakan ini adalah sangat mudah, namun di lapangan sangat susah dilakukan karena menyangkut penetapan mortalitas ikan.

Menggunakan data FAO, Costello et al, 2012 telah mulai menganalisis peluang ekonomi produksi "upside" dan seafood untuk perikanan. Dari pemodelan global dari Costello, diperoleh bahwa keuntungan ekonomi bisa lebih dari dua kali lipat, dan hasil bisa meningkat sektar $60 \%$, melalui perubahan manajemen perikanan. Dengan pendekatan dan kerangka analisis yang serupa, Costello dan tim akan melakukan kerjasama dengan KKP Indonesia dalam mewujudkan perikanan yang berkelanjutan yang mampu mengangkat ekonomi para pelaku usaha di Indonesia.

Pela-Tomlinson model dikenal sebagai generalisasi model surplus produksi. Namun, pendekatan ini relatif jarang diterapkan di Indonesia, termasuk di Asia. Derivasi model Pela-Tomlinson adalah sebagai berikut: Apabila $r=$ kecepatan tumbuh intrinsik, $\mathrm{X}=$ Biomassa, $\mathrm{K}=$ kapasitas Lingkungan dan, $\mathrm{h}=$ hasil tangkapan, maka:

$$
\begin{aligned}
& G(X)=r X^{n}-\frac{r}{K} X \text { s if } n>0 \\
& G(X)=\frac{r}{K} X^{n}-r X \quad \text { if } 0<n<1
\end{aligned}
$$

Misal $0<\mathrm{n}<1$

$$
\frac{d X}{d t}=\frac{r}{K} X^{n}-r X-h
$$

Apabila $\frac{r}{K}=A$ dan $r=B$

Sehingga $\quad \frac{d X}{d t}=A X^{n}-B X-h$

Dimana/Where:

$\mathrm{h}=$ Hasil tangkapan/ Catch

Persamaan (2) dapat ditulis dengan cara melinerasisasi menjadi:

$$
X_{t+1}-X_{t}=\Delta X_{t}
$$


Hasil tangkapan per upaya (CPUE) adalah $\bar{u}=\frac{h}{E}$

Misal, jumlah tangkapan $=h=q E X==>\bar{u}=q X-\rightarrow X=\frac{\bar{u}}{q}$

Setelah linearisasi persamaan (2), maka

$$
\Delta x_{t}=A\left[\frac{\bar{u}}{q}\right]^{n}-B\left[\frac{\bar{u}}{q}\right]-h
$$

Untuk dua waktu yang berurutan yaitu $\mathrm{t}=0 \rightarrow \mathrm{t}=1$

Rata-rata nilai stok pada dua periode tersebuat adalah:

$$
\begin{aligned}
& x_{t}(0)=\frac{x_{t-1}+x_{t}}{2} \\
& x_{t}(1)=\frac{x_{t}+x_{t+1}}{2}
\end{aligned}
$$

Setelah dikurangi:

$$
x_{t}(1)-x_{t}(0)=\Delta x_{t}=\frac{x_{t+1}-x_{t-1}}{2}
$$

Karena $x_{t}=\frac{U_{t}}{q}$

maka: $\frac{U_{t+1}-U_{t-1}}{2 q}=\frac{\Delta x_{t}}{2}=\frac{\Delta U_{t}}{q}$

Persamaan ini disubstitusi balik ke persamaan (2) akan menjadi

$$
\frac{\Delta u_{t}}{q}=A\left[\frac{\bar{u}}{q}\right]^{n}-B\left[\frac{\bar{u}}{q}\right]-h
$$

atau $\Delta u_{t}=\frac{A}{a^{n-1}} \bar{u}^{n}-B \bar{u}-q h$

Persamaan tersebut dapat disederhanakan menjadi:

$$
\begin{gathered}
\qquad \frac{\Delta U_{t}}{q}=A\left[\frac{\bar{U}}{q}\right]^{n}-B\left[\frac{\bar{U}}{q}\right]-h \\
\text { atau } \Delta U_{t}=\frac{A}{q^{n-1}} \bar{U}^{n}-B \bar{U}-q h \\
\Delta u_{t}=\alpha \bar{U}^{n}-\beta \bar{U}-q h
\end{gathered}
$$

dimana

$$
\begin{aligned}
& \alpha=\frac{A}{q^{n-1}}=\frac{r}{K q^{n-1}} \\
& \beta=B=r
\end{aligned}
$$

Tiga parameter tersebut dapat diperoleh dari regresi persaman berikut:

$$
Y=\Delta U_{t} ; x_{1}=\bar{U}^{n} ; x_{2}=U ; x_{3}=h
$$

sedangkan parameter $\mathrm{r}$ dan $\mathrm{K}$ didapat dari alpha dan beta:

$$
K=\frac{r}{q^{n-1} \alpha}
$$

\section{HASIL DAN PEMBAHASAN}

\section{Gambara Umum Perikanan Kakap Merah}

Data yang digunakan adalah data dari Direktorat Jenderal Perikanan Tangkap yang sudah diolah oleh salah satu peneliti dari Pusat Penelitian dan Pengembangan Perikanan Tangkap. Data tersebut adalah menggunakan data time series dari tahun 1977 sampai dengan tahun 2014 berupa data produksi kakap merah, upaya tangkap dan CPUE. Data tersebut juga sudah dielaborasi dengan data SOI berupa data perubahan iklim dengan data CPUE. Setelah dielaborasi dapat disimpulkan bahwa data Direktorat Jenderal Perikanan tangkap tersebut dapat digunakan karena siklus CPUE sesuai dengan siklus perubahan iklim, seperti yang tertera pada Gambar 1.

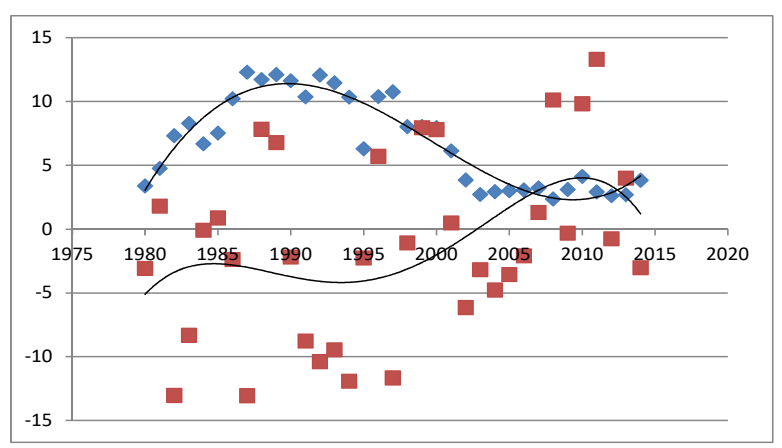

Gambar 1. Perbandingan Data CPUE Kakap Merah dan Data Perubahan Iklim dari SOl.

Figure 1. Comparation Of CPUE Data of Red Snapper With Climate Change Data (SOI) Data.

Alat Tangkap yang digunakan untuk kakap merah adalah pukat hela dan pukat tarik, dimana kedua jumlah alat tangkap tersebut bervariasi dari tahun ke tahun. Terjadi penurunan alat tangkap pukat hela dan pukat tarik dari periode tahun 19771982, dimana dari 8.869 unit unit menjadi 2.671 unit. Kemudian dari tahun 1995 terjadi lagi kenaikan menjadi 8.404 unit, tapi turun lagi jumlahnya menjadi 5.814 unit pada tahun 1996. Pada tahun 2002 sampai dengan tahun 2003 terjadi lonjakan yang cukup tajam yaitu mencapai 16.220 unit menjadi 27.495 unit. Hal ini diduga karena terjadi 
karena ada penambahan dari alat tangkap rawai dasar kesalahan pencatatan, dimana pada tahun 2003 ada 3.302 unit rawai dasar yang menangkap kakap merah dapat dilihat pada Gambar 2.

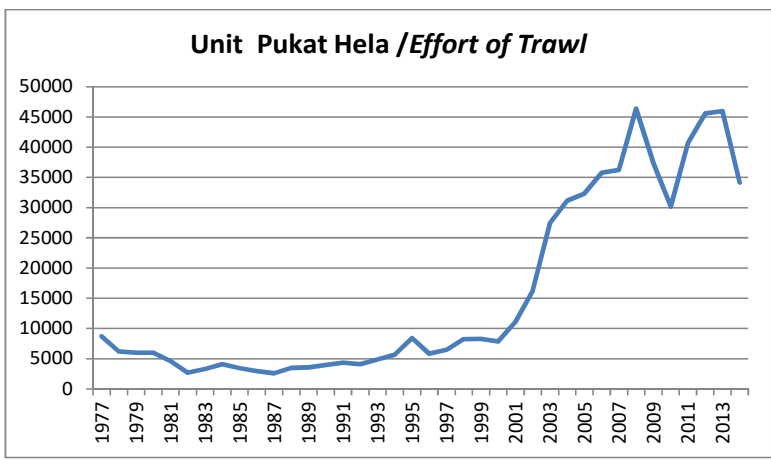

Gambar 2. Data Jumlah Alat Tangkap Pukat Hela dan Tarik di Indonesia dari Tahun 1977-2014.

Figure 2. Effort Data Of Red Snapper In Indonesia, 1977 -2014.

Pada gambar di bawah ini terlihat bahwa produksi kakap merah cenderung meningkat dari tahun ke tahun (1977-2014). Jika pada tahun 1977, produksi kakap merah hanya 14.515 ton, pada tahun 2014 sudah meningkat secara tajam mencapai 130.301 ton. Dapat disimpulkan, produksi kakap merah di Indonesia, tidak berkorelasi positif terhadap jumlah alat tangkap yang digunakan. Karena ada tahun tertentu jumlah alat tangkap meningkat secara tajam, tapi produksi kakap merah hanya meningkat secara tipis. Produksi kakap merah meningkat dipengaruhi oleh faktor kesuburan perairan, belum terjadi degrasi lingkungan, dan penggunaan alat tangkap sesuai dengan daya dukung lingkungan.

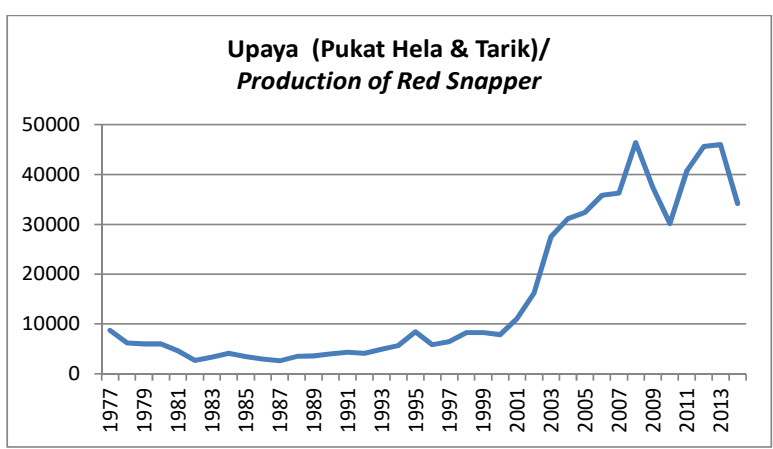

Gambar 3. Data Produksi Kakap Merah dari Alat Tangkap Pukat Hela dan Pukat Tarik 1977-2014.

Figure 3. Production Of Red Snapper From Hela Trawl And Pull Trawl 19772014.
CPUE/trip bersifat siklik, dimana naik dan turun dalam tahun tertentu. Misalnya dari tahun 1977 sampai dengan tahun 1983, CPUE/kapal naik dari 1,7 ton menjadi 8,3 ton. Namun turun pada tahun 1984 menjadi 6,7 ton. Jika dibandingkan CPUE/trip sudah melewati optimal, dimana CPUE/trip pada tahun 2013 sudah mencapai $26 \mathrm{Kg} /$ trip. Berdasarkan wawancara dengan nelayan yang menangkap kakap merah di Pantura pada Maret 2016, menurut mereka ukuran kakap merah yang ditangkap dari tahun ke tahun menjadi lebih kecil.

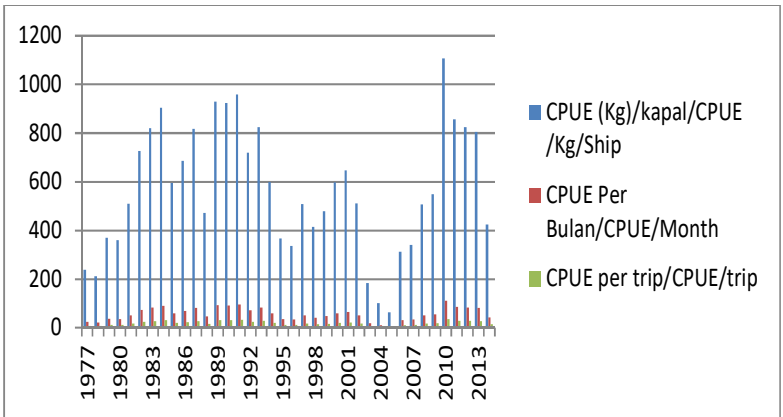

Gambar 4. Data CPUE Kakap Merah 1977-2014. Figure 4. CPUE Of Red Snapper 1977-2014.

Pada Gambar 5 terlihat harga kakap merah (Rp/ton) berbentuk siklik, dimana naik dan turun pada tahun tertentu. Namun secara umum harga kakap merah meningkat dari tahun ke tahun, misalnya pada tahun 2000 harga kakap merah hanya $5.607(\mathrm{Rp} / \mathrm{kg})$, namun pada tahun 2013 sudah mencapai $23.726(\mathrm{Rp} / \mathrm{kg})$. Tapi harga kakap merah tergantung pada musim, dimana pada musim puncak harga ikan turun, namun pada musim packelik bisa meningkat.Terjadi penurunan harga pada pada kurun waktu 2003 dan 2004, pada tahun 2003 harganya Rp7.604, dan tahun 2004 turun menjadi Rp6.668.

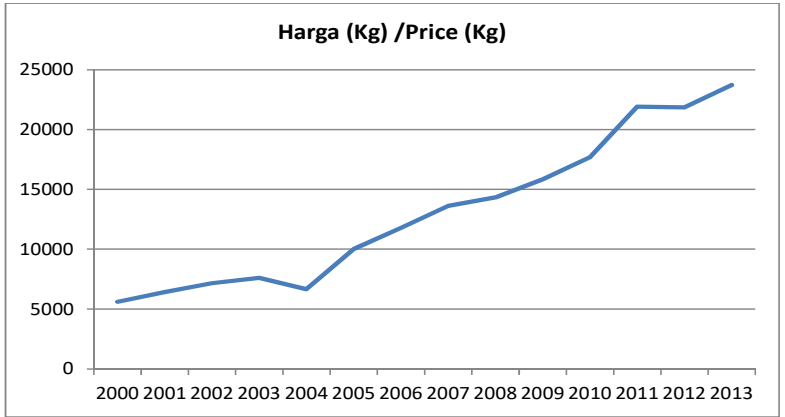

Gambar 5. Data Harga Kakap Merah Dari 2002- 2012.

Figure 5. Price Of Red Snapper 2002-2012. 
Tabel 2. Struktur Biaya Operasional Kakap Merah.

Table 2. Operational Cost Of Red Snapper.

\begin{tabular}{lrr}
\hline \multicolumn{1}{c}{ Kategori/Category } & $\begin{array}{c}\text { Cantrang/ } \\
\text { Nylon Net }\end{array}$ & $\begin{array}{c}\text { Pancing Rawai/ } \\
\text { Drift Gill Net }\end{array}$ \\
\hline Pendapatan Total (Rp)/Total Revenue (IDR) & $89,397,611$ & $38,690,481$ \\
Pengeluaran Total (Rp)/Total Cost (IDR) & - & - \\
Biaya Penyusutan (Rp)/ Depreciation Cost (IDR) & $4,870,422$ & $\mathbf{1 , 2 3 2 , 9 8 0}$ \\
Biaya Perawatan (Rp)/ Maintenance Cost (IDR) & $2,641,240$ & $1,572,156$ \\
Biaya Perizinan (Rp)/Permitence Cost (IDR) & 22,037 & 23,529 \\
Biaya Operasional (Rp)/ Operational Cost (IDR) & $37,279,900$ & $8,816,563$ \\
\hline Keuntungan Total (Rp)/Total Profit (IDR) & $\mathbf{4 4 , 5 8 4 , 0 1 0}$ & $\mathbf{7 , 0 4 5 , 2 5 1}$ \\
\hline
\end{tabular}

Sumber: Giamurti et al. (2015)/Source: Giamurti et al. (2015)

Pada Tabel 2 terlihat bahwa satu kali trip dari alat tangkap pancing rawai membutuhkan biaya sebesar Rp8.816.563; dimana komposisi biaya yang paling tinggi adalah pada biaya operasional. Komposisi biaya yang tidak terlalu besar adalah pada biaya perizinan sebesar Rp23.529.

\section{Analisa Pengelolaan Kakap Merah Berkelanjutan}

Dari model Pella- Tomlison yang dihasilkan terindikasi bahwa carrying capacity sebesar 3.303.371, 77, dimana dibawah rata-rata produksi antaratahun 1977-2014. Jika dilihat darimodel biologi yang diindikasikan dengan growth rate sebesar 0.06 , yang artinya model pertumbuhan produksi sejalan dengan bahwa carrying capacity bahwa rata-rata produksi dari tahun 1977- 2017 diatas carrying capacity dan growth rate. Nilai bio-massa dari Kakap Merah pada kondisi berkelanjutan sebesar 1.321.289 ton, dimana biomassa pada kondisi riil pada tahun 2014 adalah sebesar 2.683.110 ton. Artinya, bio-massa pada kondisi riil lebih besar ketimbang bio-massa pada berkelanjutan. Dampak lanjutannya adalah sudah terjadi upaya penangkapan kakap merah pada kondisi kritis, sehingga jumlah bio-massa kondisi riil melebihi kondisi berkelanjutan.

Ada pun persamaan fungsional dari metodelogi yang merupakan hasil penelitian seperti dibawah ini:

$$
\begin{aligned}
& Y=a+b x \\
& Y=\Delta U t \quad=\text { CPUE }(1970-2014) \\
& \Delta U t \quad=\alpha U^{n}-\beta U-q h \\
& \text { CPUE }(1970-2014)=0.188+1.33 \mathrm{x}
\end{aligned}
$$

Adapun hasil analisis dari parameter biologi bisa dilihat pada Tabel 3, dimana $r$ asumsi sebesar 0.06 , $\mathrm{K}$ sebesar 3.30 , dan biomassa pada kondisi berkelanjutan sebesar 1.3

Pada gambar di bawah ini terlihat bahwa jumlah upaya tangkap kakap merah dari tahun 1980 - 2014 cenderung meningkat, jika tidak dilakukan pengaturan pengelolaan perikanan, maka mulai dari tahun 2015, jumlah upaya tangkap di atas jumlah upaya lestari (MSY). Tapi jika dilakukan pengelolaan perikanan berdasarkan prinsip-prinsip pengelolaan perikanan lestari maka mulai tahun 2020 upaya tangkap di bawah jumlah upaya lestari (MSY).

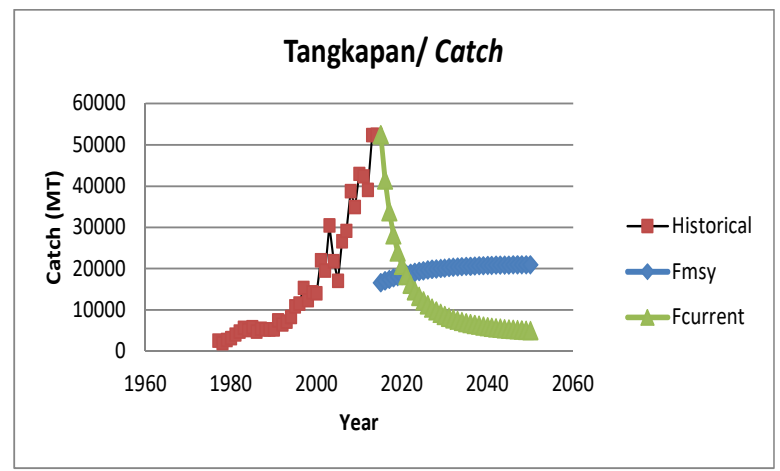

Gambar 6. Jumlah Upaya Tangkap dan Jumlah Upaya Tangkap Lestari.

Figure 6. Effort Total and Effort Sustainable.

Pada Gambar 7 terlihat bahwa biomassa massa naik semenjak tahun 1980 sampai pada tahun 2000. Akan tetapi mulai turun dari tahun 2000 sampai tahun 2014, jika tidak dilakukan kebijakan untuk mengurangi degradasi sumber daya maka penurunan biomassa akan terjadi penurunan terus hingga tahun 2050. 
Tabel 3. Parameter Biologi dan Parameter Ekonomi Dari Model Pella-Tomlinson Kakap Merah. Table 3. Biology Parameters And Economic Parameters Of Pella-Tomlinson Of Red Snappers.

\begin{tabular}{|c|c|c|}
\hline \multicolumn{2}{|l|}{ Model Pella-Tomlinson Kakap Merah/Pella-Tomlinson Red Snapper } & \multirow{2}{*}{$\begin{array}{r}\text { Satuan/Units } \\
\text { Units/Units }\end{array}$} \\
\hline Parameter/Parameters & Nilai/Values & \\
\hline$\Delta /$ Parameter Pertumbuhan endegenous/Growth parameter endegenous & 0.188 & -- \\
\hline r asumption /Rate Pertumbuhan/Growth Rate & 0.06 & \\
\hline K/Daya Dukung/Carrying capacity (endogenous) & $3,303,371.77$ & \\
\hline $\begin{array}{l}\text { xMSY/Bio-massa pada kondisi berkelanjutan/ Biomass-Maximum Sustainable } \\
\text { Yield }\end{array}$ & $1,321,289$ & Ton/Metric tons \\
\hline fMSY/ Upaya Tangkap berkelanjutan/ Biomass-Maximum Sustainable Yield & 0.06 & -- \\
\hline $\begin{array}{l}\text { E2014/Bio-massa tahun } 2014 \text { dari Model Pella-Tomlinson/Biomass get from } \\
\text { the model }\end{array}$ & $2,683,110$ & Ton/Metric tons \\
\hline r2014/Mortalitas/Fishing Mortality & 0.014569027 & -- \\
\hline $\begin{array}{l}\text { r1977/ Bio-massa tahun 1977/ Biomass get from the model (Biomass/ } \\
\text { biomass MSY) }\end{array}$ & 0.9 & \\
\hline $\begin{array}{l}\text { r2014/Estimasi bio-massa pada tahun 2014/ Current estimated stock biomass } \\
\text { relative to BMSY }\end{array}$ & 2.03 & -- \\
\hline $\begin{array}{l}\text { E2014/ Mortalitas pada tahun 2014/ Current estimated total fishing mortality } \\
\text { relative to FMSY }\end{array}$ & 0.24 & -- \\
\hline $\begin{array}{l}\text { MSY/ Upaya Tangkap pada kondisi berkelanjutan/ Effort on maximum } \\
\text { sustainable yield }\end{array}$ & 79,277 & Ton/Metric tons \\
\hline c/biaya/Cost & 839,688 & USD/unit of fishing \\
\hline $\mathrm{p} /$ Harga/Price & 4,370 & USD/metric ton \\
\hline $\begin{array}{l}\lambda / \text { Keuntungan pada kondisi open accsees/ Dependency of entry-exit } \\
\text { dynamics to profit under open access }\end{array}$ & 0.1 & -- \\
\hline ß/Konstanta/ Non-linear fishing cost constant & 1.33 & -- \\
\hline
\end{tabular}

Sumber: Data diolah (2016)/Source:Data Processed (2016).

Jika dilakukan pengelolaan perikanan secara berkelanjutan maka secara perlahan terjadi kenaikan biomassa secara perlahan dari tahun 2020 sampai dengan tahun 2050.

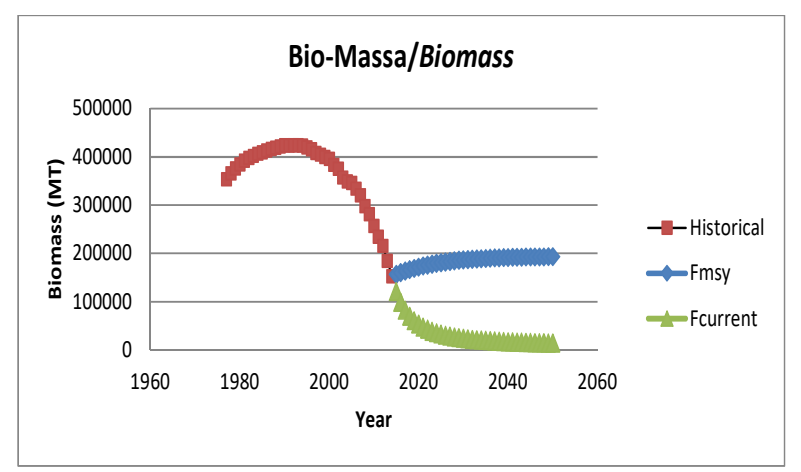

Gambar 7. Biomassa Total dan Bio Massa
Lestari.

Figure 7. Bio-mass Total and Bio-mass Sustainable.

Pada Gambar 8 terlihat bahwa keuntungan yang diterima nelayan meningkat dari tahun 1980 sampai dengan tahun 2014. Jika tidak dilakukan pengelolaan perikanan secara sustainable maka keuntungan yang diterima nelayan akan menurun, karena terjadi penurunan hasil tangkapan. Jika dilakukan pengelolaan perikanan secara berkelanjutan maka keuntungan yang diterima nelayan akan meningkat lagi dari tahun 2020 sampai dengan tahun 2050 .

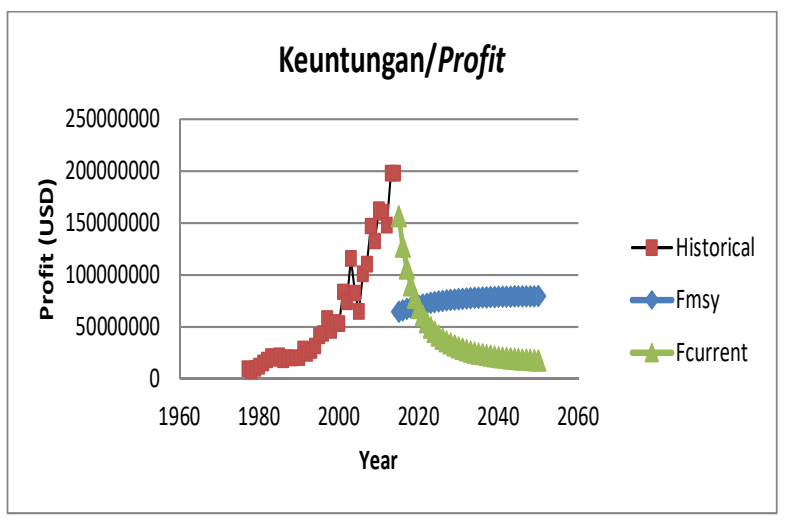

Gambar 8. Keuntungan Total dan Keuntungan Lestari.

Figure 8. Profit Total and Profit at Sustainable. 


\section{KESIMPULAN DAN IMPLIKASI KEBIJAKAN}

\section{Kesimpulan}

Hasil analisis menginsikasikan, pertama, jika tidak dilakukan pengelolaan upaya tangkap pada perikanan kakap merah, maka mulai dari tahun 2015, jumlah upaya tangkap di atas jumlah upaya lestari (MSY), hal ini disebakan ada indikasi peningkatan jumlah upaya tangkap kakap merah dari tahun 1980-2014. Kedua, penurunan bio-massa mengakibatkan keuntungan yang diterima nelayan cenderung menurun, karena itu diharapkan pemerintah mendorong masyarakat nelayan melakukan penangkapan berdasarkan prinsip-prinsip pengelolaan sumber daya berkelanjutan seperti pembatasan upaya tangkap perikanan. Jika dilakukan pengelolaan perikanan secara berkelanjutan maka keuntungan yang diterima nelayan akan meningkat lagi dari tahun 2020 sampai dengan tahun 2050.

\section{Implikasi Kebijakan}

Diharapkan pemerintah mengambil intervensi kebijakan pembatasan upaya tangkap dimana berdasarkan prinsip-prinsip pengelolaan perikanan lestari, sehingga mulai tahun 2020 upaya tangkap di bawah jumlah upaya lestari (MSY). Ada indikasi penurunan bio-massa dari tahun 2000-2014, sehingga pemerintah perlu membuat kebijakan untuk mengurangi laju degradasi sumber daya . Jika dilakukan kebijakan pengelolaan perikanan secara berkelanjutan maka secara perlahan terjadi kenaikan biomassa secara perlahan dari tahun 2020 sampai dengan tahun 2050.

\section{UCAPAN TERIMA KASIH}

Kami penulis mengucapkan terima kasih kepada semua anggota tim penelitian dari Kementrian Kelautan dan Perikanan dan dari University California Santa Barbara dan para pihak lainnya yang telah membantu dalam penyediaan data sekunder.

\section{DAFTAR PUSTAKA}

Blaber S.J.M., C.M. Dichmont, R.C. Buckworth, Badrudin, B. Sumiono, S.Nurhakim, B. Iskandar, B. Fegan, D.C. Ramm \& J. P. Salini. 2005. Shared stocks of snappers (Lutjanidae) in Australia and Indonesia:Integrating biology, population dynamics and socio-economics toexamine management scenarios. Reviews in Fish Biology and Fisheries 15: 111-127. DOI 10.1007/s11160-005-3887-y.
Costello, C., Ovando, D. Hilborn, R, Gaines, S.D., Deschenes, O \& S.E. Lester. 2012. Status and Solutions for the World's Un assessed Fisheries. Science 338: 517-520.

Fauzi, A. 2003. Persepsi Terhadap Nilai Ekonomi Sumber daya. USAID-Indonesia Coastal Resource Management Project Koleksi Dokumen Proyek Pesisir 1997-2003.

Giamurti, A.S.R., A.N. Bambang dan A.D.P. Fitri. 2015. Analisis Pemasaran Hasil Tangkapan Kakap Merah (Lutjanus Sp.) Di Pelabuhan Perikanan Nusantara Brondong, Lamongan, Jawa Timur. Journal of Fisheries Resources Utilization Management and Technology 4 (4): 8-17

Gordon, H.S. 1954. The Economic Theory of a CommonProperty Resource: The Fishery. Journal of Political Economy 62 (2):124-142.

Hilborn, R. 1976. Optimal Exploitation of Multiple Stocks by A common Fishery: A New Methodology. Journal Fisheries Resouces 33 (2): 1-5

Koeshendrajana, S., Y.D. Sari, Mira, dan A. Zamroni. 2008. Riset Tingkap Pemanfaatan Pengelolaan Sumber Daya Perikanan Tangkap (Laporan Teknis, tidak dipublikasikan). Balai Besar Riset Sosial Ekonomi Kelautan dan Perikanan. Jakarta.

Mira, dan Y.D. Sari. 2012. Analytic Hierarchy Process Pengelolaan Armada Penangkapan Ikan untuk Kategori Sumber daya Perikanan "over-exploted". Prosiding. Seminar Hasil Penelitian Sosial Ekonomi Kelautan dan Perikanan. Jakarta.

Nabunome, W. 2007. Model Analisis Bioekonomi Dan Pengelolaan Sumber Daya Ikan Demersal (Studi Empiris di Kota Tegal), Jawa Tengah. (Tesis Program Pasca Sarjana, tidak dipublikasikan). Universitas Diponegoro. Semarang.

Pauly, D., V. Christensen, S. Guénette, T.J. Pitcher, U. R. Sumaila, C.J. Walters, R. Watson \& D. Zeller. 2002. Towards sustainability in world fisheries. Nature: 689-695.

Pella, J.J. and P.K. Tomlinson. 1969. A Generalized Stock Production Model. Bull. Inter-Am. Trop. Tuna Comm., 13: 419-496.

Sahri, M. 2004. Studi Tingkat Pemanfaatan Sumber daya Perikanan Untuk Pengelolaan Penangkapan Di Wilayah Perikanan Lokal Dan Evaluasi Terhadap Penetapan Angka JTB. Fakultas Perikanan Universitas Brawijaya. Malang.

Santoso, D. 2016. Potensi Lestari dan Status Pemanfaatan Ikan Kakap Merah dan Ikan Kerapu Di Selat Alas Propinsi Nusa'Tenggara Barat. Jurnal Biologi Tropis 16 (1): 24-33.

Schaefer, M.B. 1954. Some Aspect of the Dynamic of Populations Important to the Management of Commercial Marine Fisheries. Bull. Inter-Am. Trop. Tuna Comm., 1: 27-56. 
1957. Some Consideration of Population Dynamics and Economics Relation to the Management of Marine Fisheries. Journal of the Fisheries Research Board Canada, 14: 669-681.

Sriati. 2011. Kajian Bio Ekonomi Sumber Daya Kakap Merah Yang Didaratkan Di Pantai Selatan Tasikmalaya, Jawa Barat. Jurnal Akuatika2 (2):79-90.

Usman, A., O.K. Sumadiharga dan M.P.Patria. 2014. Pengelolaan Sumber daya Ikan Kakap Merah (Lutjanusspp.) Di Perairan Utara Cirebon, Laut Jawa. Jurnal Teknologi Perikanan Dan Kelautan5 (1) : 65-74.

Walters, C.J. and R. Hilborn. 1976. Adaptive Control of Fishing Systems. J. Fish. Res. Board Canada, 33: $145-159$.

Zulbainarni, N. 2015. Teori dan Praktik Pemodelan Bioekonomi Dalam Pengelolaan Perikanan Tangkap. Edisi Revisi. IPB Press. Bogor. 